\title{
Conduit roughness and dye-trace breakthrough curves: why slow velocity and high dispersivity may not reflect flow in distributed systems
}

\author{
J.D. GULLEY, ${ }^{1,2}$ P. WALTHARD, ${ }^{2,3}$ J. MARTIN, ${ }^{4}$ A.F. BANWELL,,${ }^{5,2}$ D.I. BENN,,${ }^{2,6}$ \\ G. CATANIA ${ }^{1,7}$ \\ ${ }^{1}$ Institute for Geophysics, University of Texas at Austin, Austin, TX, USA \\ E-mail: gulley.jason@gmail.com \\ ${ }^{2}$ Department of Arctic Geology, The University Centre in Svalbard, Longyearbyen, Norway \\ ${ }^{3}$ Department of Environmental Sciences, University of Basel, Basel, Switzerland \\ ${ }^{4}$ Department of Geological Sciences, University of Florida, Gainesville, FL, USA \\ ${ }^{5}$ Scott Polar Research Institute, University of Cambridge, Cambridge, UK \\ ${ }^{6}$ School of Geography and Geosciences, University of St Andrews, St Andrews, Fife, UK \\ ${ }^{7}$ Department of Geological Sciences, University of Texas at Austin, Austin, TX, USA
}

\begin{abstract}
Dye-trace breakthrough curves (BTCs) that increase in velocity and decrease in dispersivity through a melt season have been interpreted as indicating a switch from a distributed to a conduit subglacial drainage system, but this interpretation has not been validated in glaciers where the drainage system configuration was independently known. To test if processes other than a change in the configuration of the subglacial drainage system could produce similar BTCs, we measured BTCs from a persistent, mapped subglacial conduit beneath Rieperbreen, Svalbard, which lacks a distributed system because it is frozen to its bed. This conduit produced slow and highly dispersed BTCs early in the melt season when meltwater delivery rates were low, and fast and sharply peaked BTCs after the snowpack had retreated past the injection moulin. At Rieperbreen, the seasonal evolution of BTCs was controlled by decreases in conduit roughness as increased rates of meltwater delivery increased the relative submergence depths of rocks on the conduit floor. Because seasonal changes in roughness can produce slow and highly dispersed BTCs, dye-tracing studies may not be capable of uniquely identifying subglacial drainage system configurations. As a result, conduits may form earlier in melt seasons than previously recognized.
\end{abstract}

\section{INTRODUCTION}

The configuration of the subglacial drainage system that dominates a glacier bed is thought to be an important control on basal water pressure and ice sliding speeds (Fountain and Walder, 1998; Benn and Evans, 2010). Distributed systems have low hydraulic capacity, so modest increases in the rate of meltwater delivery can generate large increases in basal water pressure (Kamb, 1987; Fountain and Walder, 1998). Increased basal pressure and meltwater flow are thought to destabilize distributed systems, forcing them to collapse into integrated networks of conduits (Kamb, 1987). In contrast, conduits have greater hydraulic capacity, which allows them to better drain surface meltwater inputs as well as the adjacent distributed system, ultimately decreasing subglacial water pressure and sliding speeds (Mair and others, 2002; Anderson and others, 2004).

Shifts between distributed and conduit subglacial drainage systems have widely been inferred from temporal changes in breakthrough curves (BTCs) obtained from dyetracing studies (Seaberg and others, 1988; Willis and others, 1990; Fountain, 1993; Hock and Hooke, 1993; Nienow and others, 1998). In these studies, dye is injected into moulins and BTCs are recorded at discharge points or proglacial streams near glacier termini. These data are used to calculate the velocity and dispersivity of tracer flowing through subglacial hydrologic systems so that traces conducted at different moulins or from the same moulin at different times can be compared (Hubbard and Glasser,
2005). Transit velocity, $v$, is typically calculated from the straight-line distance between the injection point and the discharge point divided by the time from injection until the time of peak concentration. Dispersivity, $d(\mathrm{~m})$, is commonly used to define the rate of spreading of dye from BTCs. It is the ratio of the degree of spreading of dye (dispersion, $D\left(\mathrm{~m}^{2} \mathrm{~s}^{-1}\right)$ ) to transit velocity $\left(\mathrm{m} \mathrm{s}^{-1}\right)$.

Changes in velocity and dispersivity have been widely used to infer shifts between conduit and distributed subglacial drainage systems at individual moulins and across glaciers (Seaberg and others, 1988; Willis and others, 1990; Fountain, 1993; Hock and Hooke, 1993; Nienow and others, 1998; Bingham and others, 2005). One widely cited study was conducted on Haut Glacier d'Arolla, Switzerland, where seasonally increasing velocities and declining dispersivities were interpreted as indicating a switch from a distributed to a channelized subglacial drainage system (Nienow and others, 1998). The increased velocity and decreased dispersivity generally coincided with the passage of the retreating snowline up-glacier, suggesting the timing of this switch was controlled by the increased volume and diurnal variability of meltwater inputs associated with the thinning and depletion of the snowpack (Nienow and others, 1998; Willis and others, 2002). In particular, the large diurnal variations in supraglacial recharge that occur following the removal of the snowpack have been suggested to be important in driving the pressure perturbations necessary to destabilize linked cavities within the distributed 


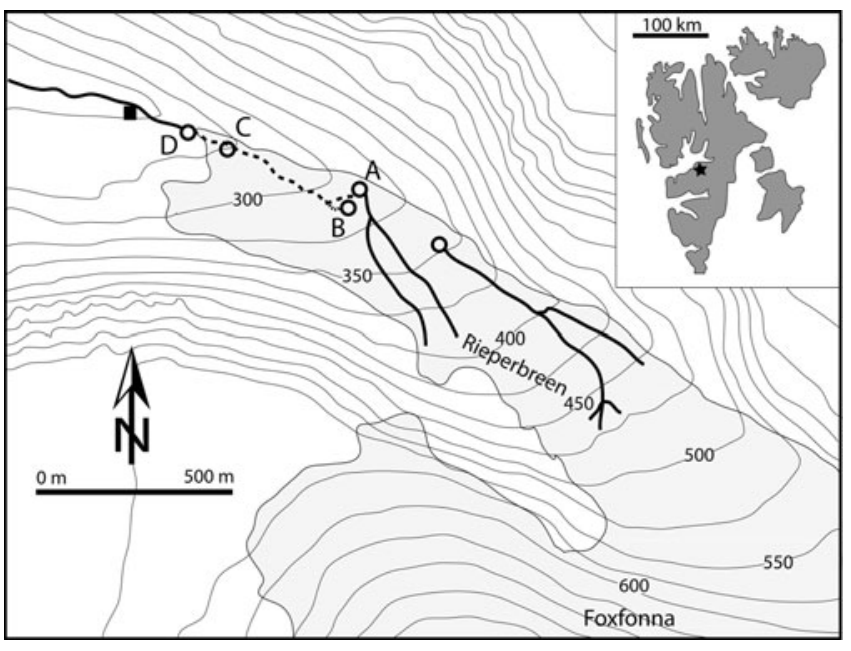

Fig. 1. Rieperbreen location map. Dye was injected in the moulin at point A. Moulin B was used as the access point to the englacial and subglacial drainage system in all years. A small hole in the roof of the subglacial conduit at point $C$ provided access to the most downstream portions of the drainage system in spring and summer 2010. Water discharged from the glacier at point D, and the field fluorometer was installed at the location indicated by the black square.

system and ultimately form conduits (Nienow and others, 1998; Willis and others, 2002).

Other studies show that multiple processes other than changes in the configuration of subglacial drainage systems affect BTCs (Nienow and others, 1996; Schuler and others, 2004). Repeat tracer tests over diurnal melt cycles from single moulins produced BTCs with diurnal variations in velocity and dispersivity that were of similar magnitude to seasonal changes. Generally, these diurnal traces generated higher velocities and less dispersed BTCs when surface melt rates were higher during the day than at night when surface melt rates were low, indicating that the rate of meltwater delivery may also affect BTCs. Because these diurnal investigations were conducted late in the melt seasons after conduit flow had become well established, these changes in BTC could be driven by changes in the rate of meltwater delivery to subglacial conduits in lieu of changes in the configuration of the subglacial drainage system.

The rate of meltwater delivery to an existing conduit may alter BTCs in multiple ways, including changes in conduit diameter, variations in hydraulic gradients, and changes in tracer storage time within moulins. Sharply peaked BTCs with high velocities could result if conduits enlarge during the day as rapid delivery of water maintains high conduit water pressure, offsets creep closure, and allows melting of the walls to increase conduit diameter and hydraulic capacity. Conversely, low delivery of water at night will allow creep closure, make conduits less efficient, and generate more dispersed BTCs with lower velocities (Schuler and Fischer, 2003, 2009). Although creep closure has negligible control on conduit hydrology over diurnal timescales where glaciers are only a few hundred meters thick (Werder and others, 2010), it becomes increasingly important as ice thicknesses approach $1000 \mathrm{~m}$ (Covington and others, 2012). Hydraulic gradient and velocity are positively correlated, resulting in elevated velocities during the day when melt rates increase, and lower velocities at night when melt rates decrease (Nienow and others, 1996). This effect is offset when tracer is stored in moulins, thereby delaying the BTC (Schuler and Fischer, 2009; Werder and others, 2010).

Changes in roughness have also been proposed to exert an important, though largely unconstrained, control on BTCs (Nienow and others, 1996; Schuler and Fischer, 2003). Loosely defined, roughness is a resistance force caused by bedforms or projections from the channel (i.e. rocks). This force is empirically parameterized relative to an idealized frictionless circular conduit to account for reduction in flow velocity. In glaciological studies, roughness is commonly parameterized as Manning roughness, $n$, though other types of hydraulic roughness parameters exist. Holding hydraulic gradient, flow path length and conduit diameter constant, conduits with higher roughness should have lower velocities and more highly dispersed BTCs than conduits with lower roughness (Schuler and Fischer, 2003). Effects of roughness on BTCs are poorly known in subglacial flow because hydraulic diameters of subglacial conduits, which are needed to solve for roughness, are largely inaccessible. As a result, how variations in roughness affect BTCs remains largely unknown.

This prior work indicates that BTCs have similar velocity and dispersivity responses to multiple forcings, suggesting unique interpretation of processes controlling their shapes may not be possible (Nienow and others, 1996; Schuler and Fischer, 2003, 2009; Schuler and others, 2004; Werder and others, 2010). Here we contribute to understanding of controls on BTCs by using field data to evaluate how seasonal changes in roughness in conduits affect transit velocities and dispersivities derived from BTCs. We report on nine traces conducted in a subglacial conduit beneath the thin, cold-based Rieperbreen, Svalbard. This subglacial conduit has a known and fixed geometry and no subglacial tributaries downstream of the injection point, fixing many of the variables that are unconstrained in other locations and allowing us to assess the effects of meltwater delivery and roughness on BTCs. Our results suggest that changes in roughness may produce BTCs that mimic the shape of BTCs that have been interpreted to reflect the shift between conduit and distributed systems.

\subsection{Rieperbreen}

Rieperbreen is an outlet glacier of Foxfonna ice cap (Fig. 1) and is located near the main settlement of Longyearbyen in Svalbard (Lyså and Lønne, 2001). The glacier and the subglacial conduit beneath it have many attributes that make it ideal for investigating recharge effects on dye BTCs. Rieperbreen is frozen to its bed (Lyså and Lønne, 2001) and thus lacks a distributed subglacial drainage system. A conduit exists at the bed, however, which evolved from a supraglacial stream by the process of incision and roof closure (termed 'cut and closure' by Gulley and others, 2009). Conduit flow processes alone thus control BTCs because exchange with porous subglacial till or linked cavities is not possible. The conduit persists between years and, based on repeat visits between September 2006 and March 2010, its morphology varies little from one year to the next. The ice overlying the conduit is $<30 \mathrm{~m}$ thick, making creep closure rates negligible. The conduit is incised in frozen till, limiting its enlargement over seasonal timescales. It has large cross sections (Fig. 2) and, since it is incised in frozen till, is likely to remain at atmospheric pressure for most of the melt season. If the conduit experienced pressurized flow conditions for extended periods of time, 
the overlying ice would have melted to enlarge the conduit rather than incising into till. Seasonal changes in hydraulic gradient are thus small compared to glaciers where hydraulic gradients increase as water backs up in moulins (Schuler and Fischer, 2009; Werder and others, 2010).

These conduit characteristics make Rieperbreen ideal to assess the effects of changing meltwater delivery rates and the associated changes in roughness on BTCs. Although a similar study could have been carried out on a proglacial stream, its flow would be modulated by the subglacial drainage system, which would be less constrained than at Rieperbreen (Jobard and Dzikowski, 2006; Flowers, 2008). In addition, snow and ice deposits can dam proglacial streams and alter the BTCs. Snow and ice blockages cannot occur within the Rieperbreen conduit because it is covered by the glacier. While the seasonal changes in roughness that occur in the Rieperbreen subglacial conduit result from changes in flow depth in an open channel, we can relate these changes in roughness that would occur during subglacial conduit enlargement using the Manning equation. The Manning equation calculates flow in non-circular pipes and open channels by converting irregular cross sections to circular pipes of equivalent diameter. The Manning equation is discussed in greater detail in Section 2.4.

\subsection{Conduit description}

Three major supraglacial streams sink into moulins on Rieperbreen (Fig. 1). These moulins are the upstream ends of cut-and-closure conduits (Gulley and others, 2009) and were not formed by water sinking into a crevasse (cf. Stenborg, 1969). Field observations and maps from 1996 indicate there was no subglacial conduit at that time and the only drainage beneath the surface of the glacier was along a lateral meltwater channel a few tens of meters long (Lyså and Lønne, 2001). Although conduits in cold ice in Svalbard can persist for decades (Gulley and others, 2009), the lack of subglacial drainage features in 1996 (Lyså and Lønne, 2001) suggests the conduit below Rieperbreen may have formed recently.

The entire section of englacial and subglacial conduit was humanly traversable from the lowest moulin (point B in Fig. 1) to the discharge point at the glacier snout (point D in Fig. 1) in September 2006 when we mapped a combined total of $671 \mathrm{~m}$ of englacial and subglacial passage (Fig. 2). The moulin entrance was $44 \mathrm{~m}$ above the subglacial meltwater resurgence at the glacier snout. The floor of the subglacial conduit consisted of large boulders (Fig. 3), and gaps between individual boulders and the ice ceiling were only a few decimeters in some conduit sections (e.g. A28). The sorted floor contrasted strongly with the frozen, poorly sorted matrix-supported diamict in the walls of the Nye channel (Fig. 3). These passage morphologies are consistent with incision of the floor by winnowing of fine-grained matrix and concentration of boulders.

The cave was remapped in October 2009 and revisited in March 2010 to determine the rate of alteration by collapse or creep closure. In both October and March, the short section of conduit between cross sections $\mathrm{A} 11$ and $\mathrm{A} 13$ remained wide, but was too low to permit passage due to build-up of aufeis on the conduit floor. Sections of the conduit downstream of A11 were accessible via a small hole in the ceiling near station A8 (point C, Fig. 1) that appeared in summer 2010. Finally, collapse of a $30 \mathrm{~m}$ long block of thin ice near the discharge point in 2009 made passage through the lower exit impossible. Although these minor changes occurred

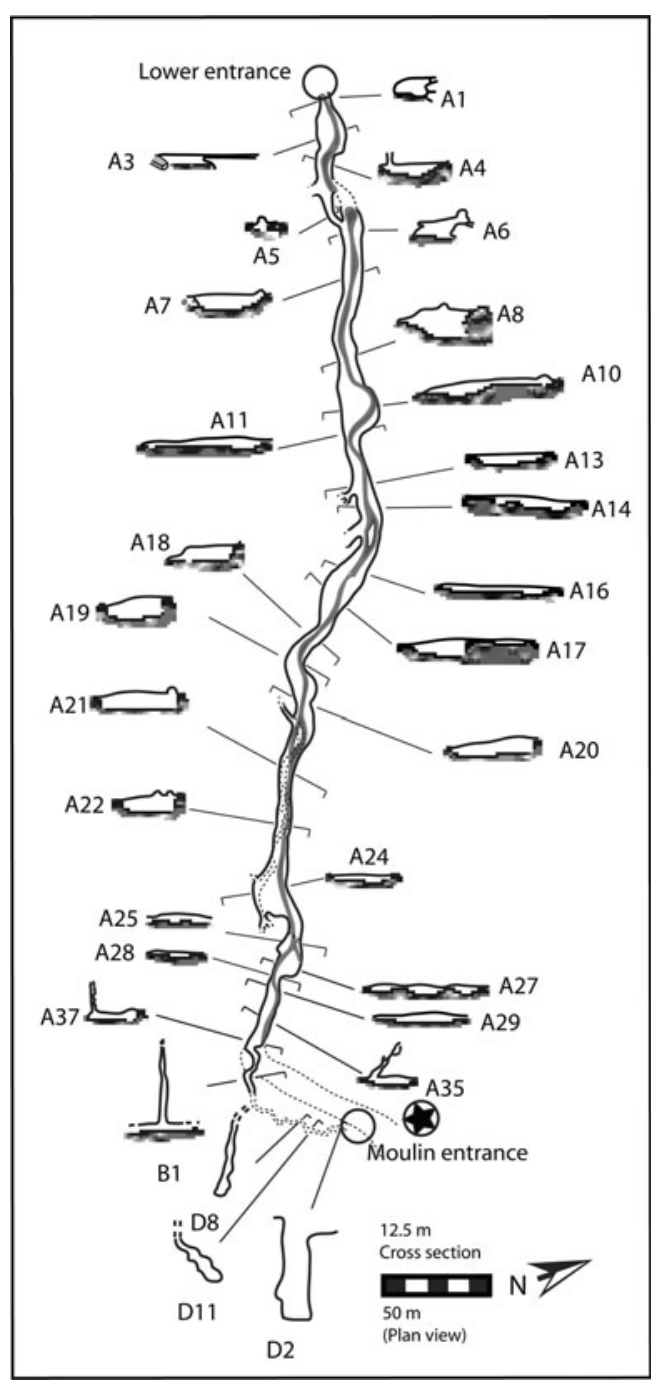

Fig. 2. Map of the subglacial conduit beneath Rieperbreen. Dotted lines indicate passage continues but was not surveyed. Black star represents supraglacial recharge point in October 2009 and dye injection point. Note the difference in north arrow direction between Figures 1 and 2 . Conduit cross sections drawn $4 \times$ plan scale.

between the two mapped times, the conduit changed little, reflecting its stability over interannual timescales.

In September 2006, the lowest of the three main moulins on the glacier was at the position marked 'Moulin entrance' in Figure 2 (point A, Fig. 1). By October 2009, the supraglacial stream had incised its way into another, preexisting portion of the subglacial conduit and sank at the point marked with a black star (point B in Fig. 1). The new moulin bypassed most of the englacial cut-and-closure conduit and delivered meltwater to the bed directly and water no longer flowed into the original moulin B (Fig. 1). Dye traces were injected into the new moulin (indicated with the black star in Fig. 1) starting on 14 June 2010 when meltwater first started emerging from the front of the glacier, and continued nearly weekly through 4 August 2010 .

\section{METHODS}

\subsection{Dye tracing}

We measured $10-25 \mathrm{~mL}$ of Rhodamine WT (20\% active ingredient) in the field using a graduated cylinder calibrated at $1 \mathrm{~mL}$ increments, and added it to a $1 \mathrm{~L}$ opaque nalgene 


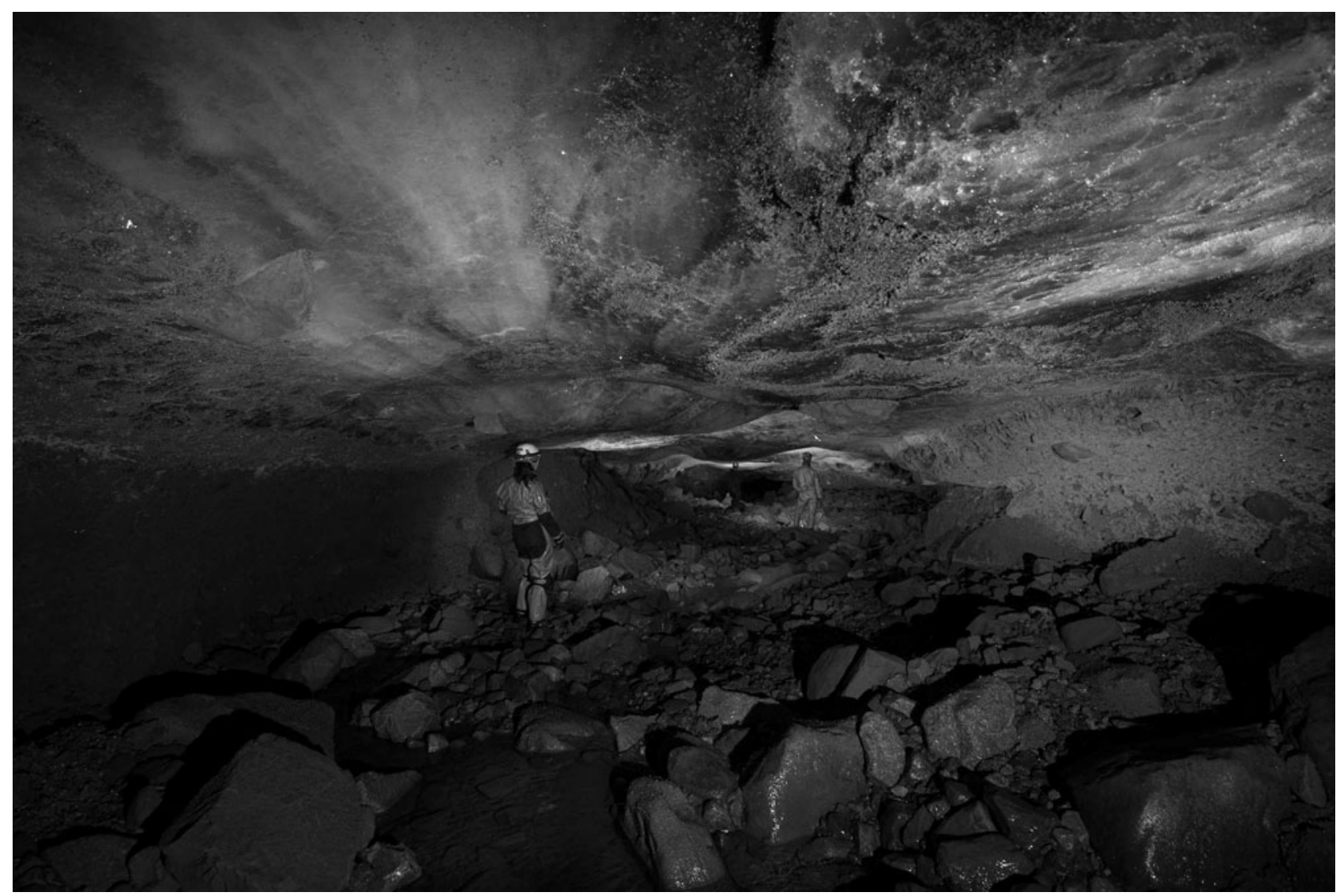

Fig. 3. Large boulders on passage floors contrast with poorly sorted, fine-grained subglacial till in passage walls (at left). Photo taken at survey station A19 (Fig. 1).

bottle. Complete transfer of dye was accomplished by adding small volumes of stream water to the cylinder and decanting into the $1 \mathrm{~L}$ bottle until the graduated cylinder was completely clear. The $1 \mathrm{~L}$ bottle was topped up with water from the proglacial stream and mixed thoroughly. Snow was excavated from the moulin, and the dye solution was injected directly into water cascading into the moulin. All injections reported here were made from the same location (point A, Fig. 1) beginning on 14 June 2010, less than 1 week after meltwater began emerging from the front of the glacier. Dye traces were conducted through $\sim 500 \mathrm{~m}$ of mapped subglacial conduit. Dye concentrations were measured and logged at $30 \mathrm{~s}$ intervals with a Turner Model $10 \mathrm{AU}$ field fluorometer $\sim 100 \mathrm{~m}$ downstream of the subglacial meltwater resurgence. The total distance of the trace was $\sim 600 \mathrm{~m}$. Dye injections continued through the summer and were conducted near the same time each day, within 2 hours of 13:00. Dispersivity was calculated using the techniques of Seaberg and others (1988).

\subsection{Discharge}

We were unable to gauge rates of meltwater delivery to the moulin during the early season due to ponding in the snowpack. A stage-discharge relationship could not be developed for the proglacial stream due to channel migration. Continuous discharge data are therefore not available. Discharge was calculated from the dye-trace BTCs using the dilution method (Hubbard and Glasser, 2005) assuming a $100 \%$ dye recovery. We consider complete recovery to be reasonable because the subglacial conduit consisted only of a short, unbranching passage and exchange with the frozen till was unlikely. Because the recession curve of the 14 June trace was incomplete, we measured discharge for this trace by timing how long it took for a float to travel $2 \mathrm{~m}$ of the proglacial stream and multiplied the velocity by the channel area.

\subsection{Channel flow conditions}

Plots of the log of the discharge versus the log of the velocity can be used to distinguish, roughly, between flow in open channels and pipe-full conditions at glacier beds (Nienow and others, 1996; Palmer, 2007) according to

$$
v=k Q^{m}
$$

where $k$ and $m$ are empirically derived constants; $m$ should equal 1 if conduits are pipe-full since any change in discharge, $Q$, must be caused by an increase in velocity, $v$. In conduits with free-surface streams, some of the increase in $Q$ can be accommodated by an increase in crosssectional area of flow within the open conduit without an increase in $v$ and, as a result, $m$ will be $<1$. Equation (1) reflects flow conditions at Rieperbreen because it contains a single conduit and because it does not exchange water with the surrounding bed. Networks of conduits allow water to back up into tributary conduits, invalidating assumptions used in Eqn (1) (cf. Nienow and others, 1996; Schuler and Fischer, 2009). Additionally, velocity-discharge relationships will be affected where conduits can exchange significant amounts of water with their beds or where glaciers are hydraulically lifted from their beds.

Since conduit geometry is known at our site, we can also calculate how flow depth changes with discharge at each 


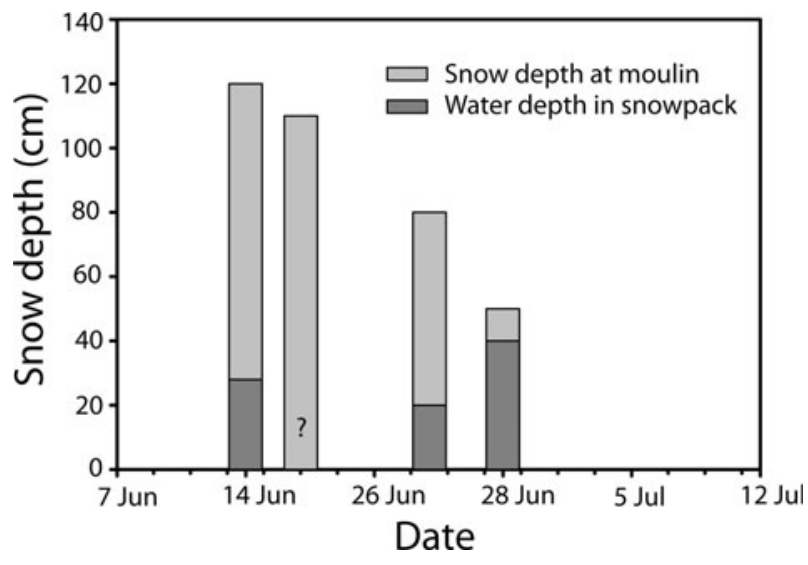

Fig. 4. Snow depth and water depth within the snowpack.

conduit cross section. First we calculate the cross-sectional area, $A$, of flow,

$$
A=\frac{Q}{v}
$$

and solve for the conduit flow depth, $d_{\text {flow, }}$ at each station by dividing $A$ by the width, $w$, of the conduit:

$$
d_{\text {flow }}=\frac{A}{W}
$$

If $d_{\text {flow }}$ is lower than the measured height of the ceiling, flow is in an open channel.

\subsection{Manning roughness}

Manning roughness coefficient, $n$, has units of $\mathrm{sm}^{-1 / 3}$ and can be calculated by solving the Gauckler-StricklerManning equation for $n$ :

$$
n=\frac{R_{\mathrm{h}}^{2 / 3} S_{0}^{1 / 2}}{v}
$$

where $R_{\mathrm{h}}$ is the hydraulic radius (defined as the crosssectional area divided by wetted perimeter), $S_{0}$ is the hydraulic gradient and $v$ is the average cross-sectional flow velocity. Calculation of the hydraulic radius converts flow in open channels or non-circular cross sections to a circular pipe with equivalent hydraulic properties. We use data from each of our dye traces to determine how $n$ varies through the melt season. We calculate $R_{\mathrm{h}}$ using an average stream width of $5 \mathrm{~m}$ in the subglacial conduit that was determined from conduit surveys and the flow depth that was calculated using Eqns (2) and (3). $S_{0}$ is taken to be the surveyed hydraulic gradient of the subglacial portions of the conduit (0.043).

\section{RESULTS}

\subsection{Snow depth}

On 14 June, snow depth in a pit excavated by the moulin was $120 \mathrm{~cm}$, and depth of the water layer at the base of the snowpack was $28 \mathrm{~cm}$ (Fig. 4). While water level was not recorded on 17 June, the snowpack had decreased an additional $10 \mathrm{~cm}$. By 28 June, the water level was nearly the same height as the snowpack, and the snowline had retreated past the moulin by 4 July.

\subsection{Breakthrough curves}

The shape of BTCs evolved systematically over the period that the snowpack was melting out. They became more peaked and had fewer tailing effects as the snowpack thinned (Fig. 5a). The 14 June trace had a slow rise to peak concentration over $45 \mathrm{~min}$ and then concentrations continued to decrease for another 2.5 hours. Unfortunately, dye concentration measurements had to be terminated before background concentrations were reached, so the full length of the tail is unknown. The 17 June trace had a much faster rise to peak concentration ( $\sim 25 \mathrm{~min}$ ) than the 14 June trace, and tailing effects, while still present, were less prominent. By 4 July, BTCs had greater symmetry, and most traces for the remainder of the study rose to peak concentrations in $\sim 5 \mathrm{~min}$ (Fig. $5 \mathrm{a}$ and b).

\subsection{Proglacial discharge}

On average, discharge increased nearly linearly from the beginning of the melt season from a low of $0.04 \mathrm{~m}^{3} \mathrm{~s}^{-1}$ on 14 June to $0.77 \mathrm{~m}^{3} \mathrm{~s}^{-1}$ on 4 July. Discharge dropped back to $0.44 \mathrm{~m}^{3} \mathrm{~s}^{-1}$ on 23 July and then rebounded to a maximum of $1.07 \mathrm{~m}^{3} \mathrm{~s}^{-1}$ on 4 August (Fig. 6a). We calculated a discharge of $>3 \mathrm{~m}^{3} \mathrm{~s}^{-1}$ on 11 July, but, based on flow observations in the field, this value is unreasonable and is not plotted.

\subsection{Tracer transit velocity}

Velocities increased through the early part of the melt season and peaked along with the estimated peak discharge in early August (Fig. 6b). The lowest velocity of $0.07 \mathrm{~m} \mathrm{~s}^{-1}$ was recorded on 14 June. Velocities increased systematically
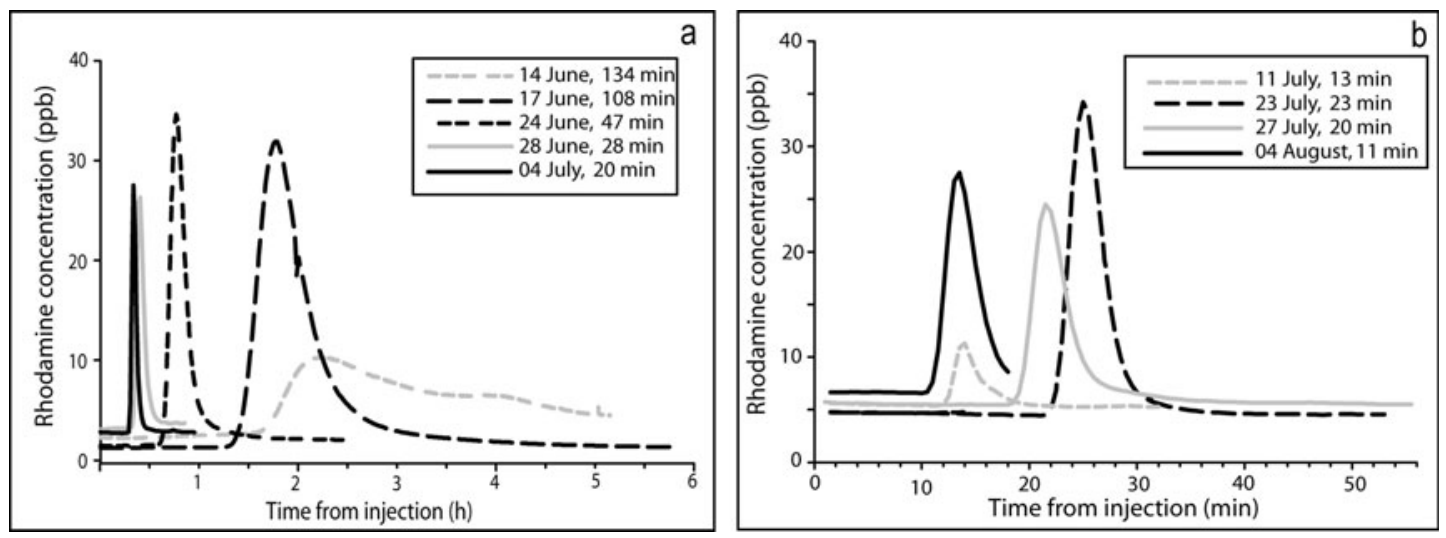

Fig. 5. (a) Dye-trace BTCs during the retreat of the snowpack past the injection moulin. The snowline migrated past the moulin on 4 July. (b) Dye-trace BTCs from traces conducted from 11 July to 5 August. Note the change in scale on the $x$ axis between (a) and (b). 

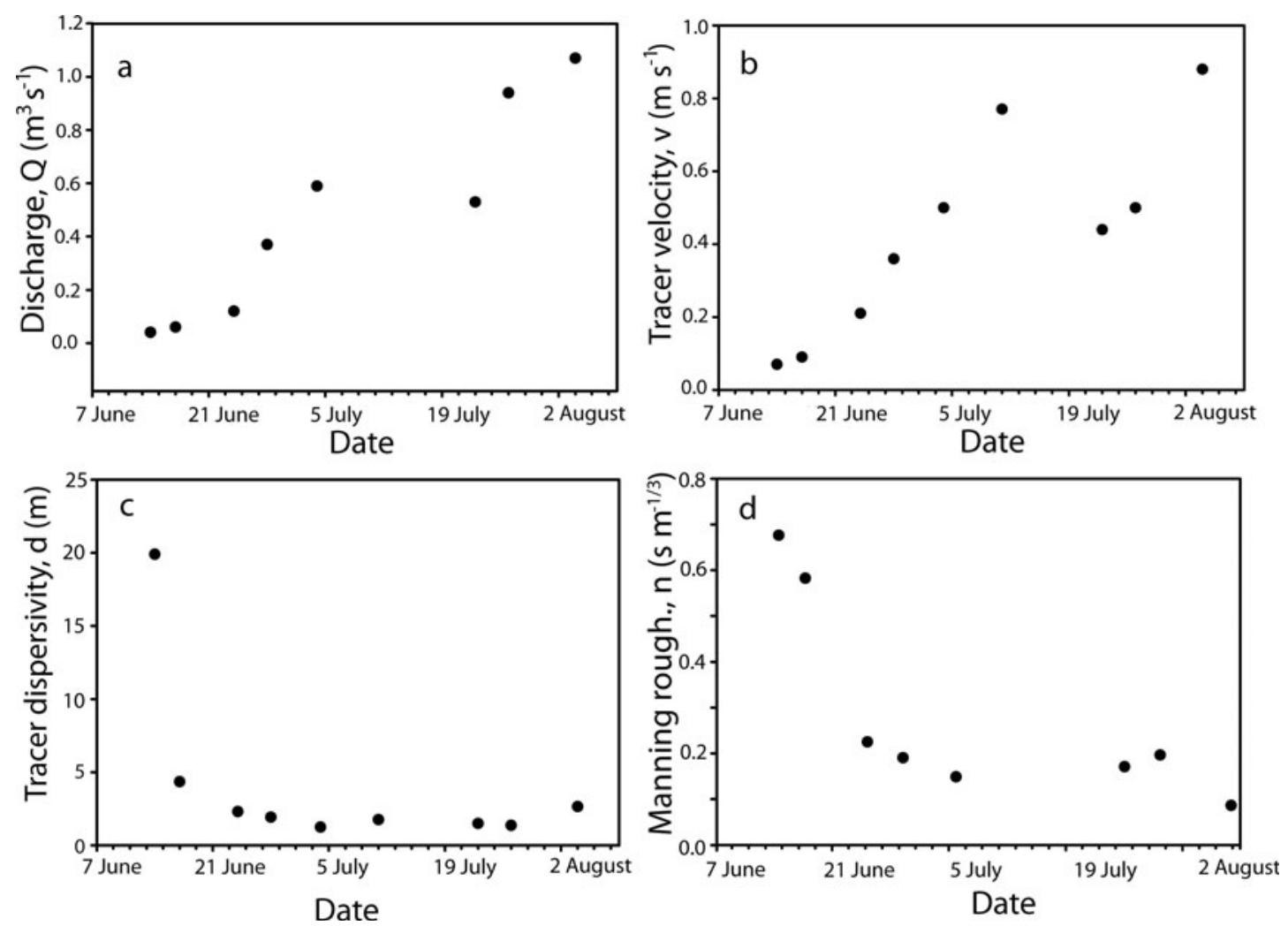

Fig. 6. (a) Discharge, $Q$, at the glacier snout, (b) tracer velocity, $v$, (c) tracer dispersivity, $d$, and (d) Manning roughness, $n$, through time.

to $0.77 \mathrm{~m} \mathrm{~s}^{-1}$ through 11 July before dropping back to $\sim 0.5 \mathrm{~m} \mathrm{~s}^{-1}$ on 23 and 27 July. The highest velocity of $0.88 \mathrm{~m} \mathrm{~s}^{-1}$ was recorded on 4 August.

\subsection{Dispersivity}

Early-season BTCs show lower velocities and higher dispersivities than BTCs recorded later in the season (Figs 5a and 6c; Table 1). For example, the 14 June trace had a dispersivity of $19.9 \mathrm{~m}$ (Fig. 6c). Dye discharged from the glacier for 4 hours, and the difference between peak and background concentration was small (Fig. 5a). Dispersivity dropped sharply to $4.3 \mathrm{~m}$ on 17 June (Fig. 6c) and continued declining to $1.2 \mathrm{~m}$ on 4 July when the snowpack retreated past the injection moulin. Decreases in dispersivity also coincided with decreased tailing in BTCs. For instance, the
14 June trace rose from background to peak concentration in $\sim 45$ min but the decline to background continued for $>3$ hours before the trace had to be terminated. Dispersivity remained below $2 \mathrm{~m}$ for all the traces conducted between 28 June and 27 July and increased slightly, to $2.7 \mathrm{~m}$, on 4 August. Visually, these decreases in dispersivity are seen as BTCs that become progressively more peaked, and exhibit progressively less tailing, during the removal of the snowpack (Fig. 5a and b). Once the snowpack has retreated past the moulin, BTCs have similar shapes (Fig. 5) and dispersivities (Fig. 6c).

\subsection{Manning roughness}

Manning roughness, $n$, was highest at the beginning of the season $\left(0.67 \mathrm{~s} \mathrm{~m}^{-1 / 3}\right)$ and declined sharply through the first

Table 1. Dye-tracing data and Manning roughness

\begin{tabular}{|c|c|c|c|c|c|c|c|c|}
\hline Date (2010) & $\begin{array}{c}Q \\
\mathrm{~m}^{3} \mathrm{~s}^{-1}\end{array}$ & $\begin{array}{c}v \\
\mathrm{~ms}^{-1}\end{array}$ & $\begin{array}{l}d \\
\mathrm{~m}\end{array}$ & $\begin{array}{l}\text { CSA } \\
\mathrm{m}^{2}\end{array}$ & $\begin{array}{l}\text { Avg. depth } \\
\text { m }\end{array}$ & $\begin{array}{l}P \\
\mathrm{~m}\end{array}$ & $\begin{array}{l}R_{\mathrm{h}} \\
\mathrm{m}\end{array}$ & $\begin{array}{c}n \\
\mathrm{~s} \mathrm{~m}^{-1 / 3}\end{array}$ \\
\hline 14 Jun & 0.04 & 0.07 & 19.89 & 0.57 & 0.114 & 5.23 & 0.11 & 0.68 \\
\hline 17 Jun & 0.06 & 0.09 & 4.34 & 0.67 & 0.134 & 5.27 & 0.13 & 0.58 \\
\hline 24 Jun & 0.12 & 0.21 & 2.3 & 0.57 & 0.114 & 5.23 & 0.11 & 0.23 \\
\hline 28 Jun & 0.37 & 0.36 & 1.92 & 1.03 & 0.206 & 5.41 & 0.19 & 0.19 \\
\hline $4 \mathrm{Jul}$ & 0.59 & 0.5 & 1.24 & 1.18 & 0.236 & 5.47 & 0.22 & 0.15 \\
\hline $11 \mathrm{Jul}$ & & 0.77 & 1.75 & & & & & \\
\hline $23 \mathrm{Jul}$ & 0.53 & 0.44 & 1.5 & 1.2 & 0.24 & 5.48 & 0.22 & 0.17 \\
\hline $27 \mathrm{Jul}$ & 0.94 & 0.5 & 1.36 & 1.88 & 0.376 & 5.75 & 0.33 & 0.20 \\
\hline 4 Aug & 1.07 & 0.88 & 2.65 & 1.22 & 0.244 & 5.49 & 0.22 & 0.09 \\
\hline
\end{tabular}

Notes: Q: proglacial discharge; v: tracer velocity; d: dispersivity; CSA: cross-sectional area; Avg. depth: flow depth calculated assuming average conduit width of $5 \mathrm{~m} ; P$ : wetted perimeter; $R_{\mathrm{h}}$ : hydraulic radius; $n$ : Manning roughness. 

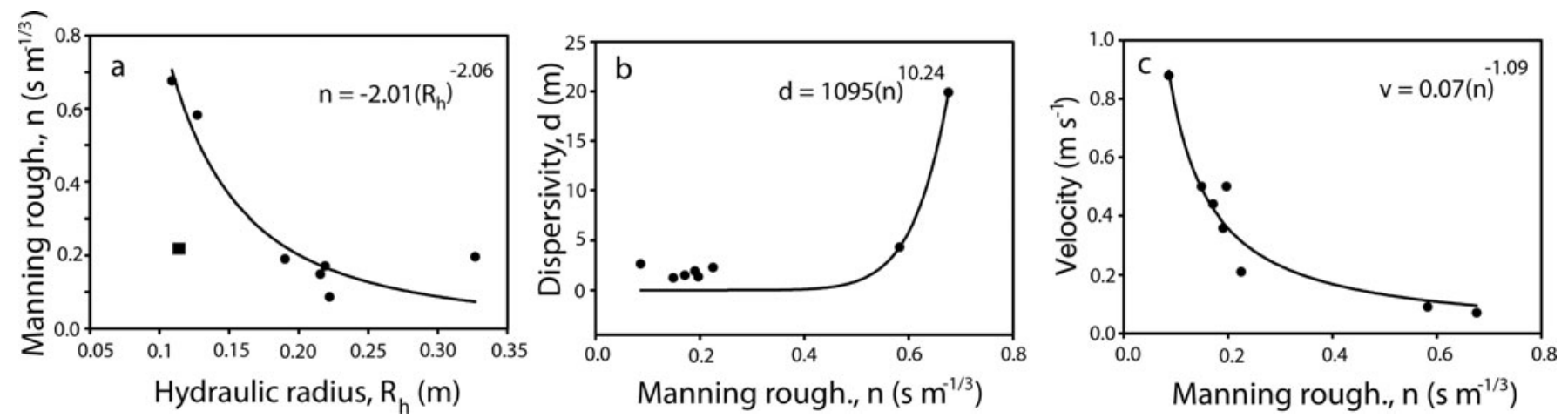

Fig. 7. (a) Manning roughness coefficient, $n$, plotted as a function of hydraulic radius, $R_{\mathrm{h}}$. (b) Dispersivity, $d$, plotted as a function of Manning roughness, $n$. (c) Tracer velocity, $v$, plotted as a function of Manning roughness, $n$. Note the goodness of fit for the power-law relationship between $n$ and $R_{\mathrm{h}}$ was improved by omitting data from 24 June outlier (shown as black square in (a)).

four traces, dropping below $0.2 \mathrm{~s} \mathrm{~m}^{-1 / 3}$ on 28 June (Fig. $6 \mathrm{~d}$ ). Values of $n$ remained below $0.22 \mathrm{~s} \mathrm{~m}^{-1 / 3}$ for the remainder of the season. Manning roughness values decreased rapidly with hydraulic radius, $R_{\mathrm{h}}$, at the beginning of the melt season (Fig. 7a), and relationships between $R_{\mathrm{h}}$ and $n$ could be fit with a power law if data from the 24 June trace were excluded. Once the hydraulic radius decreased below $0.2 \mathrm{~m}$, values of $n$ were relatively constant between 0.1 and $0.2 \mathrm{~s} \mathrm{~m}^{-1 / 3}$. Manning roughness also exhibited nonlinear relationships with tracer velocity and dispersivity that could be fit with a power law (Fig. 7b and c respectively), with velocity increasing and dispersivity decreasing as $n$ decreased. Dispersivity values became relatively constant at $1-2 \mathrm{~m}$ once $n$ decreased below $0.4 \mathrm{~s} \mathrm{~m}^{-1 / 3}$, whereas velocity continued to increase with decreases in $n$.

\subsection{Channel flow conditions}

Equation (1) was fit to the log of the discharge and the log of the velocity, resulting in an $r^{2}$ of 0.87 , and the parameters $k$ and $m$ were 0.70 and 0.69 respectively, indicating flow in open channels (Fig. 8). We also calculated changes in water depth at the subglacial conduit cross section at A16. At $14 \mathrm{~m}$ wide and with a maximum vertical extent of $1 \mathrm{~m}$ between the highest point on the ceiling and the lowest point on the floor (Fig. 2), cross section A16 is the lowest conduit cross section in the subglacial conduit. At A16, flow depths varied from $0.04 \mathrm{~m}$ at low flow to $0.09-0.13 \mathrm{~m}$ at high flow, leaving a minimum (though irregularly shaped) air space of $0.87 \mathrm{~m}$.

\section{DISCUSSION}

\subsection{Comparison with other dye-trace breakthrough curves}

Velocities and dispersivities from Rieperbreen are generally comparable to other glaciers (summarized in Willis and others, 2009) despite all our traces having occurred under atmospheric pressure. Our lowest velocity of $0.09 \mathrm{~m} \mathrm{~s}^{-1}$ was recorded for the first dye trace of the melt season and is slightly higher than the lowest velocities of $0.01 \mathrm{~m} \mathrm{~s}^{-1}$ reported from both Midtdalsbreen, Norway (Willis and others, 1990), and South Cascade Glacier, USA (Fountain, 1993). Our highest velocity of $0.88 \mathrm{~m} \mathrm{~s}^{-1}$ was on 5 August and is of a similar magnitude to the maximum reported velocity of $0.99 \mathrm{~m} \mathrm{~s}^{-1}$ recorded at Haut Glacier d'Arolla (Nienow, 1993). Our dispersivity values ranged from a minimum of $1.3 \mathrm{~m}$ on 14 July to a maximum of $19.9 \mathrm{~m}$ on
14 June and are within ranges reported from other glaciers. For example, dispersivity ranged from 0.7 to $71 \mathrm{~m}$ on Midtdalsbreen (Willis and others, 1990) and from 0.9 to $53 \mathrm{~m}$ on Haut Glacier d'Arolla (Nienow, 1993).

The lower dispersivities at Rieperbreen than at other glaciers may reflect differences in flow path length, since dispersivity increases with flow path length in natural systems (Moltz and others, 1983; Gelhar and others, 1992; Glimm and others, 1993; Hauns and others, 2001). Flow path length increases dispersivity through multiple processes, including changes in the velocity structure of water and directions along flow paths (Levy and Berkowitz, 2003), dilution by additional inputs of water downstream of the injection site (Li and Loper, 2011), and temporary storage of water in eddy currents or pools (Hauns and others, 2001). These processes have been observed as temporary storage of tracer in water-filled moulins (Werder and others, 2010), hydraulic damming of up-glacier moulins caused by water backing up into tributary conduits (Nienow and others, 1996; Schuler and Fischer, 2009), dilution by multiple downstream inputs of water in conduit networks, and temporary storage of water and dye in plunge pools in englacial passages (Fountain, 1993). The lower dispersivity values observed at Rieperbreen may therefore reflect the

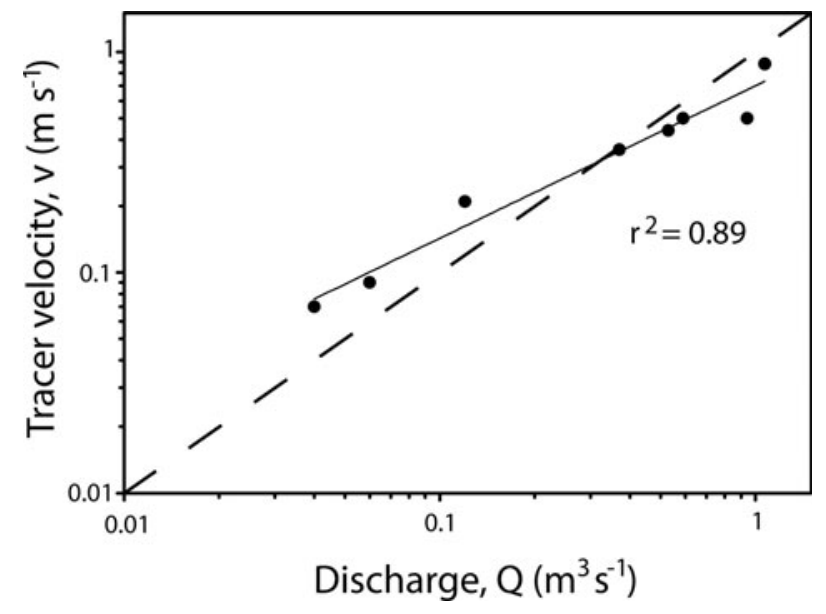

Fig. 8. The log of the discharge, $Q$, plotted against the log of the velocity, $v$. If flow occurred in a full pipe, the slope of this line would be 1 (shown here as a dashed line); however, our data have a slope of 0.69 , indicating flow in an open channel. 
fact that the conduit at Rieperbreen is shorter $(600 \mathrm{~m})$ than other sites, which are typically $>1 \mathrm{~km}$. Other potential causes for lower dispersivity at Rieperbreen relative to other glaciers include the lack of additional meltwater inputs downstream of the injection point at Rieperbreen, which dilute tracers, as well as the lack of hydraulic damming, which increases tracer travel time. Both dilution and damming are common to most other studied glaciers and are known to increase dispersivity values.

Changes through time of BTCs measured at Haut Glacier $\mathrm{d}^{\prime}$ Arolla are interpreted as examples of a distributed system evolving into a channelized system (Hubbard and Glasser, 2005; Cuffey and Patterson, 2010). The timing of the shift from distributed to channelized systems has been estimated primarily from changes in velocity, with velocities lower than $0.4-0.5 \mathrm{~m} \mathrm{~s}^{-1}$ indicating flow in distributed systems, and velocities higher than this indicating flow in conduits (Nienow and others, 1998; Mair and others, 2002; Hubbard and Glasser, 2005). Dispersivity values greater than $10 \mathrm{~m}$ are also considered to indicate flow in distributed systems, but this variable is less commonly used to identify types of flow systems. The progression of BTCs used to infer a switch from distributed to conduit systems at Haut Glacier d'Arolla (Fig. 9b) corresponded to the arrival of the snowline at the moulin (Nienow and others, 1998).

The seasonal evolution of BTCs, in both velocity and dispersivity (Nienow and others, 1998), recorded at Haut Glacier d'Arolla has been proposed to be caused by a shift from a distributed to a conduit subglacial drainage system. We obtained a similar progression of BTCs from traces conducted in the subglacial conduit at Rieperbreen, although our mapping of the Rieperbreen conduit clearly shows the lack of a distributed system (Fig. 9). Similar to Haut Glacier $d^{\prime}$ Arolla, tracer velocities at Rieperbreen are low prior to the retreat of the snowpack, with velocities increasing systematically from $0.07 \mathrm{~m} \mathrm{~s}^{-1}$ on 14 June to $0.36 \mathrm{~m} \mathrm{~s}^{-1}$ on 28 June. These velocities are less than the criterion of $<0.5 \mathrm{~m} \mathrm{~s}^{-1}$ assumed to indicate distributed systems (Nienow and others, 1998; Mair and others, 2002) but were generated in a conduit at Rieperbreen. Similar results of flow less than $0.5 \mathrm{~m} \mathrm{~s}^{-1}$ have been found in drainage systems that were presumed to have been conduit-dominated (Nienow and others, 1996; Schuler and others, 2004), but the decrease in velocities could not be unambiguously established since the conduit size and morphology were unknown. Possible causes of changes in BTCs in these studies are changes in hydraulic gradient, changes in roughness, or conduit enlargement and creep.

\subsection{Roughness and hydraulic radius control of breakthrough curves}

Recent modeling studies have advanced understanding of the controls on BTC evolution (Schuler and Fischer, 2009; Werder and Funk, 2009; Werder and others, 2010). Model solutions are likely non-unique, however, because changes in hydraulic gradient, roughness or hydraulic radius can generate similar changes in BTCs. Additionally, these models rely on tuning parameters to fit data from complex conduit networks consisting of multiple moulins that receive meltwater inputs at different times to the outputs of models that treat these complex networks as one or two pipes. Our observational results are, however, unambiguous. Log-log plots of velocity and discharge (Fig. 8) and measured discharge values compared with channel cross-sectional area show that flow in the single conduit beneath Rieperbreen was at atmospheric pressure. As a result, because changes in hydraulic gradient are fixed by the slope of the bed, which is known, and because changes in hydraulic radius can be calculated from changes in flow depth, we can use the Manning equation to solve for changes in roughness. Our study therefore allows us to more directly assess the influence of roughness on tracer dispersivity and velocity than previous studies, where drainage system configurations were not known and where tracer velocities could have been influenced by conduit network effects.

The floor of the conduit beneath Rieperbreen consists of roughness features, such as large boulders and cobbles (Fig. 3), that affect BTCs in several complementary ways. Wetted surface area decreases relative to cross-sectional area as flow depth increases, thereby increasing velocity and decreasing dispersivity. At high discharges, boulders and cobbles on the floor of the conduit are completely submerged, reducing tortuosity of flow around boulders. Flow above boulders will reduce the amount of back-eddy currents and immobile regions that can delay and temporarily store small quantities of tracer (Hauns and others, 2001). Limited ponding and back-eddy currents will increase velocity and decrease dispersivity. In contrast, during low discharges early in the melt season, emergent boulders will increase ponding and back eddies and could cause the tailing, slow velocity and elevated dispersivities observed prior to the 24 June trace (Fig. 5). Changes in roughness in open channels, such as at Rieperbreen, may also explain diurnal variability in velocity and dispersivity found late in melt seasons after conduit flow had had time to become established (cf. Nienow and others, 1996; Schuler and others, 2004). Conduit diameters will adjust to accommodate peak meltwater inflows that occur during the day, but during the night, when surface melt rates decrease, lower inflow could result in open-channel flow and high conduit roughness.

Dispersivity values at our site also declined more rapidly than some of the BTCs recorded at other glaciers. Because it seems likely that changes in dispersivity at Rieperbreen are caused primarily by changes in roughness, the more rapid decrease in dispersivity at Rieperbreen may reflect the fact that increased flow depth can increase hydraulic radii in open channels, and thus decrease roughness, much faster than pipe-full subglacial conduits can increase their hydraulic radius through melt to decrease roughness. Conduit diameters can increase with greater influx of meltwater early in the season and then decrease through creep late in the melt season. Such variation in conduit size will change roughness because the size of boulders on the conduit floors is fixed (Fig. 10). At Rieperbreen, the largest roughness changes occurred when conduit hydraulic radii were $<0.2 \mathrm{~m}$. Small conduit hydraulic radii, coupled with large boulders or other roughness elements at subglacial beds, will result in high Manning's roughness, providing a mechanism to generate the large values of $n$, which have previously been disregarded as physically implausible (cf. Nienow and others, 1996). Large magnitudes of roughness, coupled with rapid, nonlinear changes in roughness as conduits enlarge, may explain why pipe models adapted to glacier hydrological systems are more successful in reproducing proglacial hydrographs in the middle of the melt season when large conduits have formed than early in the melt season, when drainage systems are more constricted (cf. Arnold and others, 1998; Werder and Funk, 2009). 

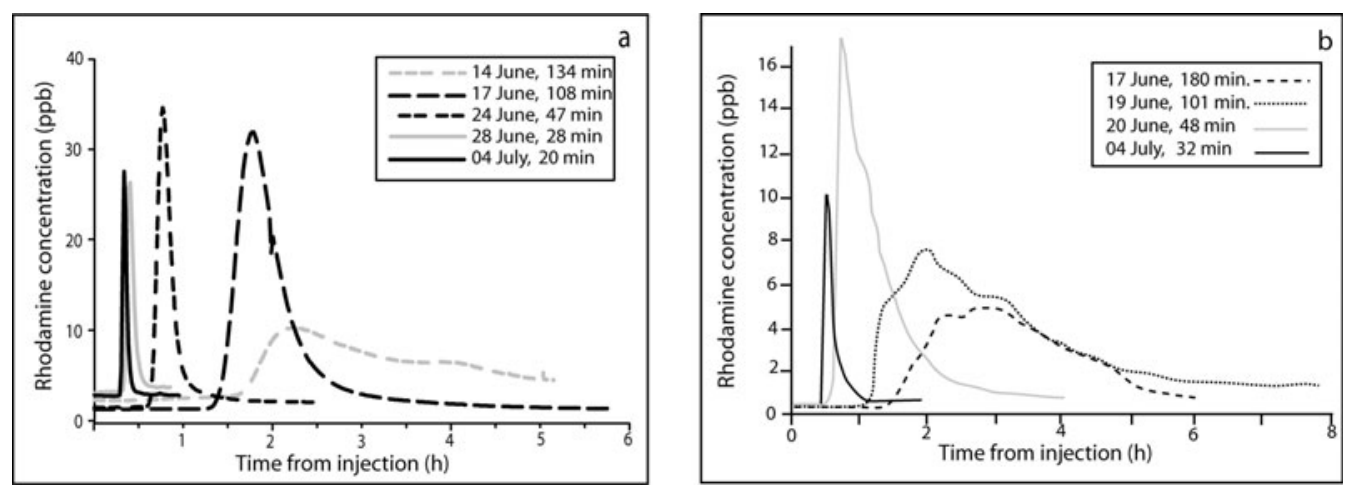

Fig. 9. BTCs collected from a persistent subglacial conduit during the retreat of the snowpack in our study (a) are qualitatively similar to BTCs from a 1990 study at Haut Glacier d'Arolla (b) (reproduced from Nienow and others, 1998). While most studies have interpreted a transition from highly dispersed BTCs to more-peaked BTCs as indicating a transition from a distributed to a channelized subglacial drainage system, all the BTCs in Figure 9a were obtained in a subglacial conduit with no possibility of influence from a distributed system.

\subsection{Implications of the configuration and evolution of subglacial drainage systems}

While temporal increases in velocity and decreases in tracer dispersivity may reflect a switch from a distributed to a conduit subglacial drainage system (Nienow and others, 1998), similar velocity and dispersivity values derived from BTCs at Rieperbreen simply result from changing relative roughness in a fully developed conduit system. Diurnal changes in tracer velocity may be caused by changes in flow depth in open channels, and seasonal changes may be caused by the enlargement of constricted conduits or other preferential, channelized flow paths. Slow and highly dispersed BTCs can also result from changes in hydraulic gradient or changes in moulin residence time (Schuler and Fischer, 2009; Werder and others, 2010). Consequently, changes in velocity and dispersivity alone may provide insufficient evidence to independently distinguish between a conduit and a distributed system.

Several studies have demonstrated that flow in conduits connected to moulins can produce slow and highly dispersed BTCs, but few studies have examined, either directly or through models, what types of BTCs a distributed system will generate. A few studies, however, have been conducted where dye was injected into boreholes. Conduits represent a small fraction of the glacier footprint, so boreholes are unlikely to be installed close to conduits (Gordon and others, 1998). Consequently, the few dye traces conducted from boreholes are more likely to represent distributed systems. In borehole injections, tracer travel times are measured in days or weeks instead of hours, and dye continues to discharge for weeks, resulting in BTCs that

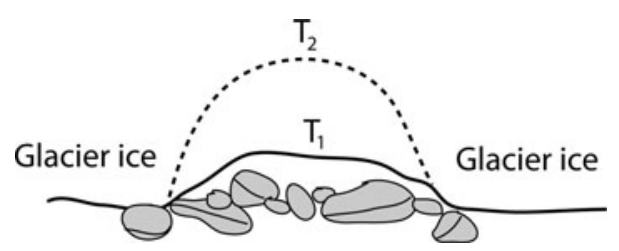

Fig. 10. Early in the melt season $\left(T_{1}\right)$, constricted conduits have small hydraulic radii relative to the height of bed roughness features, such as rocks, resulting in high roughness. Conduit enlargement by melt increases in the hydraulic radii of conduits $\left(\mathrm{T}_{2}\right)$, reducing roughness. are too highly dispersed for dispersivity values to be calculated (Hooke and Pohjala, 1994; Hock and others, 1999). Transit times from moulin injections are orders of magnitude faster than injections in boreholes, indicating moulins are connected to the fastest portions of the subglacial drainage system and that subglacial drainage is already channelized early in the melt season. If flow was not channelized, BTCs from injections made in moulins at the beginning of the melt season should be similar to BTCs collected from traces injected in boreholes.

Channelization of the drainage system during the early melt season could be caused by several processes. Past workers have suggested that creep closure of ice should cause subglacial conduits to collapse during the winter and re-form from a distributed system each melt season (Fountain and Walder, 1998; Nienow and others, 1998). Recent work suggests that constricted conduit systems may be kept open during winter by meltwater backing up into the coupled englacial system (Benn and others, 2009; Catania and Neumann, 2010). In addition, moulins are frequently (but not always) recharge points for subglacial conduits (Gulley and others, 2009) and form in approximately the same location year after year (Stenborg, 1969). The location of moulins may thus allow subglacial conduits to form along similar flow paths each year. Subglacial conduits have been mapped in the same location with similar morphologies in multiple years (Gulley and others, in press). Sediments on the floors of subglacial conduits that form in the same locations during multiple years can be winnowed of fine-grained materials (Harbor and others, 1997; Gulley and others, in press), generating high-permeability zones that could channelize flow and rapidly enlarge each melt season (Figs 3 and 12). In this scenario, the seasonal evolution of BTCs could be explained by the continued enlargement, and decreased roughness, of this channelized zone. While it could be argued that flow bifurcation by rocks at low flow in our conduit at Rieperbreen could be seen as analogous to flow in a distributed system, it is important to note that our data indicate this 'distributed' system need only be a few meters wide to generate highly dispersed BTCs and that flow in this system can be described using conduit flow equations.

While we agree that subglacial drainage systems enlarge and become more efficient through melt seasons, and that past studies have recorded increases in the hydraulic 
efficiency of subglacial drainage systems by analyzing systematic variations in dye BTCs, we do not believe these observations uniquely identify a switch from a distributed system to a channelized system. Our results, similar to other studies (cf. Schuler and others, 2004), suggest that BTCs that are frequently interpreted as indicating flow in a distributed system can be generated in conduits. As a result, subglacial conduits may form earlier in the melt season than previously thought, such as after snowpack has begun melting but before it has retreated past moulins, or conduits could be reused between years (cf. Benn and others, 2009; Catania and Neumann, 2010) but their presence might not be indicated with current interpretations of BTCs (cf. Nienow and others, 1998).

The results of this study are qualitatively similar to a recent investigation of the controls on proglacial glacier discharge hydrographs (Covington and others, 2012). Although such hydrographs were once thought to contain unique information about the configuration of subglacial drainage systems, Covington and others (2012) showed that proglacial discharge hydrographs primarily respond to changes in the rate of meltwater delivery to the subglacial drainage system and that hydrographs do not carry unique information about the configuration of subglacial drainage systems. The Covington and others (2012) study, combined with our present investigation, indicate that two of the main sources of field data that have been used to infer a switch in the configuration of the subglacial drainage system are not as conclusive as once thought. Consequently, seasonal changes in subglacial hydrological systems could be strongly influenced by seasonal changes in the hydraulic capacity of channelized zones rather than simply by changes in the configuration of the subglacial drainage system.

\section{CONCLUSIONS}

Seasonal changes in BTCs in a subglacial conduit beneath Rieperbreen were similar to BTCs that have been used to infer switches from distributed to conduit drainage systems. Beneath Rieperbreen, however, drainage was through a known conduit with a fixed geometry and changes in drainage system configuration can be ruled out. Instead, systematic changes in BTCs were caused by changes in conduit roughness. At Rieperbreen, seasonal decreases in roughness were caused by seasonal increases in water flow depth that occurred as the retreat of the snowpack increased the rate of meltwater delivery to the conduit. Increases in flow depth resulted in increased relative submergence of roughness elements at the bed, such as boulders and rocks. Tracer velocity increased and dispersivity decreased because water had less interaction and contact with rocks on the conduit floor. These changes in roughness at Rieperbreen are directly analogous to how roughness would change in pipe-full subglacial conduits beneath thicker glaciers where conduit enlargement reduces the interaction of subglacial water with rocks at the bed. Dispersivity values recorded in BTCs may therefore be higher for longer periods of time on glaciers undergoing conduit enlargement than in glaciers that experience openchannel flow because conduit enlargement requires a much longer timescale than increasing flow depth in open channels and because the wetted perimeter of closed conduits is greater than the wetted perimeter in open channels. Because changes in roughness can generate the slow and highly dispersed BTCs which have been interpreted to indicate flow in distributed drainage systems, it may not be possible to infer system morphology or configuration using BTCs. Further, because dispersivity increases with the length scale of the studied flow path, comparisons of dispersivities between different glaciers and traces conducted in different moulins on the same glacier may not be comparing like with like.

Our results do not, of course, disprove that seasonal variations in BTCs might be influenced by changes in drainage system configuration, but they do complement a growing number of studies that indicate slow and/or highly dispersed BTCs can be generated in conduits. Using changes in BTCs to infer changes in the configuration of subglacial drainage systems will remain problematic until the full range of BTCs that can be produced in conduit systems under different recharge conditions is known. While changes in BTCs may be insufficient evidence for a change in the configuration of subglacial drainage systems, dye tracing remains an effective method of delineating subglacial drainage basins (Fountain, 1993).

\section{ACKNOWLEDGEMENTS}

J. Gulley acknowledges funding from the American Philosophical Society, the Lewis and Clark Fund for Exploration and Field Research, the University of Florida and the US National Science Foundation (NSF) in the form of a Graduate Research Fellowship and a NSF Division of Earth Sciences (EAR) Postdoctoral Fellowship (No. 0946767). Gulley and Benn also acknowledge funding and logistical support from the University Centre in Svalbard. We thank A. Bergstrom, M. Temminghoff, Z. Luthi, M. Covington and I. Willis for field assistance. We thank I. Willis for conversations, and M.A. Werder and an anonymous reviewer for comments that greatly improved the manuscript.

\section{REFERENCES}

Anderson RS and 6 others (2004) Strong feedbacks between hydrology and sliding of a small alpine glacier. J. Geophys. Res., 109(F3), F03005 (doi: 10.1029/2004JF000120)

Arnold N, Richards K, Willis I and Sharp M (1998) Initial results from a distributed, physically-based model of glacier hydrology. Hydrol. Process., 12(2), 191-219 (doi: 10.1002/(SICI)10991085(199802)12:2<191::AID-HYP571>3.0.CO;2-C)

Benn DI and Evans DJA (2010) Glaciers and glaciation, 2nd edn. Hodder Education, London

Benn D, Gulley J, Luckman A, Adamek A and Glowacki PS (2009) Englacial drainage systems formed by hydrologically driven crevasse propagation. J. Glaciol., 55(191), 513-523 (doi: 10.3189/002214309788816669)

Bingham RG, Nienow PW, Sharp MJ and Boon S (2005) Subglacial drainage processes at a High Arctic polythermal valley glacier. J. Glaciol., 51(172), 15-24 (doi: 10.3189/ 172756505781829520)

Catania GA and Neumann TA (2010) Persistent englacial drainage features in the Greenland Ice Sheet. Geophys. Res. Lett., 37(2), L02501 (doi: 10.1029/2009GL041108)

Covington MD, Banwell AF, Gulley J, Saar MO, Willis I and Wicks CM (2012) Quantifying the effects of glacier conduit geometry and recharge on proglacial hydrograph form. J. Hydrol., 414(415) (doi: 10.1016/j.jhydrol.2011.10.027)

Cuffey KM and Paterson WSB (2010) The physics of glaciers, 4th edn. Butterworth-Heinemann, Oxford 
Flowers GE (2008) Subglacial modulation of the hydrograph from glacierized basins. Hydrol. Process., 22(19), 3903-3918 (doi: 10.1002/hyp.7095)

Fountain AG (1993) Geometry and flow conditions of subglacial water at South Cascade Glacier, Washington State, U.S.A.; an analysis of tracer injections. J. Glaciol., 39(131), 143-156

Fountain AG and Walder JS (1998) Water flow through temperate glaciers. Rev. Geophys., 36(3), 299-328 (doi: 10.1029/ 97RG03579)

Gelhar LW, Welty C and Rehfeldt KR (1992) A critical review of data on field-scale dispersion in aquifers. Water Resour. Res., 28(7), 1955-1974 (doi: 10.1029/92WR00607)

Glimm J, Lindquist WB, Pereira F and Zhang Q (1993) A theory of macrodispersion for the scale-up problem. Transport Porous Med., 13(1), 97-122

Gordon S, Sharp M, Hubbard B, Smart C, Ketterling B and Willis I (1998) Seasonal reorganization of subglacial drainage inferred from measurements in boreholes. Hydrol. Process., 12(1), 105-133

Gulley JD, Benn DI, Screaton E and Martin J (2009) Mechanisms of englacial conduit formation and their implications for subglacial recharge. Quat. Sci. Rev., 28(1920), 1984-1999 (doi: 10.1016/ j.quascirev.2009.04.002)

Gulley JD, Grabiec M, Martin JB, Jania J, Catania G and Glowacki P (in press) The effect of discrete recharge by moulins and heterogeneity in flow path efficiency at glacier beds on subglacial hydrology. J. Glaciol., 58(211), 926-940

Harbor J, Sharp M, Copland L, Hubbard B, Nienow P and Mair D (1997) The influence of subglacial drainage conditions on the velocity distribution within a glacier cross section. Geology, 25(8), 739-742

Hauns M, Jeannin PY and Atteia O (2001) Dispersion, retardation and scale effect in tracer breakthrough curves in karst conduits. J. Hydrol., 241(3), 177-193

Hock R and Hooke RLeB (1993) Evolution of the internal drainage system in the lower part of the ablation area of Storglaciären, Sweden. Geol. Soc. Am. Bull., 105(4), 537-546

Hock R, Iken A and Wangler A (1999) Tracer experiments and borehole observations in the overdeepening of Aletschgletscher, Switzerland. Ann. Glaciol., 28, 253-260 (doi: 10.3189/ 172756499781821742)

Hooke RLeB and Pohjola VA (1994) Hydrology of a segment of a glacier situated in an overdeepening, Storglaciären, Sweden. J. Glaciol., 40(134), 140-148

Hubbard B and Glasser N (2005) Field techniques in glaciology and glacial geomorphology. Wiley, New York

Jobard S and Dzikowski M (2006) Evolution of glacial flow and drainage during the ablation season. J. Hydrol., 330 (3-4), 663671 (doi: 10.1016/j.jhydrol.2006.04.031)

Kamb B (1987) Glacier surge mechanism based on linked cavity configuration of the basal water conduit system. J. Geophys. Res., 92(B9), 9083-9100 (doi: 10.1029/JB092iB09p09083)

Levy M and Berkowitz B (2003) Measurement and analysis of nonFickian dispersion in heterogeneous porous media. J. Contam. Hydrol., 64(3-4), 203-226 (doi: 10.1016/S01697722(02)00204-8)

Li G and Loper DE (2011) Transport, dilution, and dispersion of contaminant in a leaky karst conduit. Transport Porous Media, 88(1), 31-43 (doi: 10.1007/s11242-011-9721-1)
Lyså A and Lønne I (2001) Moraine development at a small HighArctic valley glacier: Rieperbreen, Svalbard. J. Quat. Sci., 16(6), 519-529

Mair D, Nienow P, Sharp M, Wohlleben T and Willis I (2002) Influence of subglacial drainage system evolution on glacier surface motion: Haut Glacier d'Arolla, Switzerland. J. Geophys. Res., 107(B8), 2175 (doi: 10.1029/2001JB000514)

Molz FJ, Güven O and Melville JG (1983) An examination of scale-dependent dispersion coefficients. Ground Water, 21(6), 715-725 (doi: 10.1111/j.1745-6584.1983.tb01942.x)

Nienow P (1993) Dye tracer investigations of glacier hydrological systems. (PhD thesis, University of Cambridge)

Nienow PW, Sharp MJ and Willis IC (1996) Velocity-discharge relationships derived from dye tracer experiments in glacial meltwaters: implications for subglacial flow conditions. Hydrol. Process., 10(10), 1411-1426

Nienow P, Sharp M and Willis I (1998) Seasonal changes in the morphology of the subglacial drainage system, Haut Glacier d'Arolla, Switzerland. Earth Surf. Process. Landf., 23(9), 825-843

Özger M and Yildirim G (2009) Determining turbulent flow friction coefficient using adaptive neuro-fuzzy computing technique. Adv. Eng. Softw., 40(4), 281-287 (doi: 10.1016/j.advengsoft. 2008.04.006)

Palmer AN (2007) Cave geology. Cave Books, Dayton, OH

Schuler T and Fischer UH (2003) Elucidating changes in the degree of tracer dispersion in a subglacial channel. Ann. Glaciol., 37, 275-280 (doi: 10.3189/172756403781815915)

Schuler TV and Fischer UH (2009) Modeling the diurnal variation of tracer transit velocity through a subglacial channel. J. Geophys. Res., 114(F4), F04017 (doi: 10.1029/2008JF001238)

Schuler T, Fischer UH and Gudmundsson GH (2004) Diurnal variability of subglacial drainage conditions as revealed by tracer experiments. J. Geophys. Res., 109(F2), F02008 (doi: 10.1029/2003JF000082)

Seaberg SZ, Seaberg JZ, Hooke RLeB and Wiberg DW (1988) Character of the englacial and subglacial drainage system in the lower part of the ablation area of Storglaciären, Sweden, as revealed by dye-trace studies. J. Glaciol., 34(117), 217-227

Stenborg T (1969) Studies of the internal drainage of glaciers. Geogr. Ann., $51 \mathrm{~A}(1-2), 13-41$

Werder MA and Funk M (2009) Dye tracing a jökulhlaup: II. Testing a jökulhlaup model against flow speeds inferred from measurements. J. Glaciol., 55(193), 899-908 (doi: 10.3189/ 002214309790152375)

Werder MA, Schuler TV and Funk M (2010) Short term variations of tracer transit speed on alpine glaciers. Cryosphere, 4(3), 381-396 (doi: 10.5194/tc-4-381-2010)

Willis IC, Sharp MJ and Richards KS (1990) Configuration of the drainage system of Midtdalsbreen, Norway, as indicated by dyetracing experiments. J. Glaciol., 36(122), 89-101

Willis IC, Arnold NS and Brock BW (2002) Effect of snowpack removal on energy balance, melt and runoff in a small supraglacial catchment. Hydrol. Process., 16(14), 2721-2749 (doi: 10.1002/hyp.1067)

Willis I, Lawson W, Owens I, Jacobel R and Autridge J (2009) Subglacial drainage system structure and morphology of Brewster Glacier, New Zealand. Hydrol. Process., 23(3), 384-396 (doi: 10.1002/hyp.7146) 